\title{
Mechanisms controlling the carbon stable isotope composition of phytoplankton in karst reservoirs
}

\author{
Baoli WANG,${ }^{1 *}$ Cong-Qiang LIU, ${ }^{1}$ Xi PENG, ${ }^{1,2}$ Fushun WANG ${ }^{3}$
}

${ }^{1}$ State Key Laboratory of Environmental Geochemistry, Institute of Geochemistry, Chinese Academy of Sciences, Guiyang 550002, China; ${ }^{2}$ Graduate University of Chinese Academy of Sciences, Beijing 100039, China; ${ }^{3}$ Institute of Applied Radiation, School of Environmental and Chemical Engineering, Shanghai University, Shanghai 201800, China.

*Corresponding author: baoliwang@163.com

\begin{abstract}
In order to systematically understand the mechanisms controlling the carbon stable isotope composition of phytoplankton ( $\left.\delta^{13} C_{P H Y}\right)$ in freshwater ecosystems, seasonal changes in $\delta^{13} C_{P H Y}$ and related environmental factors were determined in karst reservoirs from the Wujiang river basin, China. Substantial and systematic differences within seasons and reservoirs were observed for $\delta^{13} C_{P H Y}$, which ranged from -39.2\% to - $15.1 \%$. An increase in water temperature triggered fast growth of phytoplankton which assimilated more dissolved inorganic carbon (DIC), resulting in the increase of $\delta^{13} C_{P H{ }^{\prime}} \delta^{13} C_{D I C}$ and $p H$. When the concentration of dissolved carbon dioxide $\left(\mathrm{CO}_{2}\right)$ was less than $10 \mu \mathrm{mol} \mathrm{L}^{-1}$, phytoplankton shifted to using $\mathrm{HCO}_{3}^{-}$as a carbon source. This resulted in the sharp increase of $\delta^{13} \mathrm{C}_{P H Y^{*}}$ The carbon stable isotope composition of phytoplankton tended to decrease with the increase of Bacillariophyta, which dominated in January and April, but tended to increase with the increase of Chlorophyta and Dinophyta, which dominated in July. Multiple regression equations suggested that the influence of biological factors such as taxonomic difference on $\delta^{13} C_{P H Y}$ could be equal or more important than that of physical and chemical factors. Thus, the effect of taxonomic differences on $\delta^{13} C_{P H Y}$ must be considered when explaining the $\delta^{13} \mathrm{C}$ of organic matter in lacustrine ecosystem.
\end{abstract}

Key words: $\delta^{13} \mathrm{C}$, temperature, taxonomic difference, phytoplankton, karst reservoir.

Received: May 2012. Accepted: November 2012.

\section{INTRODUCTION}

Carbon stable isotope analysis has been used to understand biologically driven carbon cycle (e.g. Lehmann et al., 2004) as natural carbon, which is derived from different sources and subject to different biogeochemical processes, has different carbon stable isotope compositions $\left(\delta^{13} \mathrm{C}\right)$. Furthermore, $\delta^{13} \mathrm{C}$ values of aquatic biota contain important information about the contributions of different organic carbon sources to food web (Yoshii et al., 1999; Grey et al., 2000). Planktonic, benthic and terrestrial primary producers have distinct $\delta^{13} \mathrm{C}$ values (Finlay et al., 1999; Doi et al., 2010; Milligan et al., 2010) that directly reflects their food sources as there is only a slight isotopic enrichment $(<1 \%)$ during the feeding process (Yoshii et al., 1999; Post, 2002). Therefore, carbon stable isotope analysis has been proved to be a powerful tool to study carbon sources in the aquatic ecosystem. To address these questions, however, it is necessary to understand the biogeochemical characteristics of the baseline $\delta^{13} \mathrm{C}$ supporting the aquatic food web (Smyntek et al., 2012).

Phytoplankton plays an important role as it is the primary producer sustaining the lacustrine food web. The $\delta^{13} \mathrm{C}$ of phytoplankton $\left(\delta^{13} \mathrm{C}_{\mathrm{PHY}}\right)$ depends on the $\delta^{13} \mathrm{C}$ of assimilated inorganic carbon and subsequent carbon isotope fractionation $\left(\varepsilon_{\mathrm{p}}\right)$ during assimilation. Thus, variability in $\delta^{13} \mathrm{C}_{\mathrm{PHY}}$ can either be induced by a succession of species with different carbon isotope fractionation levels (Zohary et al., 1994) or be a response to seasonal fluctuations in physical, chemical and biological factors influencing the $\delta^{13} \mathrm{C}$ of inorganic carbon sources (Gu et al., 2006, 2011). Culture experiments have demonstrated that algal $\delta^{13} \mathrm{C}$ is substantially influenced both by algal physiological characteristics such as growth rate, cell size, geometry (Laws et al., 1995; Popp et al., 1998) and by physical and chemical characteristics of the environment such as $\mathrm{pH}$, temperature, daylength, light intensity (Descolas-Gros and Fontugne, 1990; Thompson and Calvert, 1994; Rost et al., 2002). These studies complicate the interpretation of carbon isotopic data in geochemical and palaeoceanographic applications (e.g. Rau et al., 1989; Freeman and Hayes, 1992) in the marine environment.

However, few field studies have been systematically conducted with respect to $\delta^{13} \mathrm{C}_{\mathrm{PHY}}$ in relation to controlling variables in freshwater (Bade et al., 2006; Vuorio et al., 2006; Marty and Planas, 2008). These studies have demonstrated that $\delta^{13} \mathrm{C}_{\mathrm{PHY}}$ show large spatial and temporal variation, but the mechanisms controlling these variations are mostly unknown. Many field studies have been carried out 
on $\delta^{13} \mathrm{C}$ of particulate organic matter (POM) in lakes (Lehmann et al., 2004; Gu et al., 2006). Gu et al. (2011) integrated $\delta^{13} \mathrm{C}_{\mathrm{POM}}$ and related environmental data on a global scale and found that the seasonal average $\delta^{13} \mathrm{C}_{\mathrm{POM}}$ displayed weak relationships with total phosphorus (TP) and chlorophyll $a(\mathrm{Chl} a)$. However, the seasonal amplitude of $\delta^{13} \mathrm{C}_{\mathrm{POM}}$ significantly correlated with these two factors. This means that phytoplankton is not always the dominant source of POM, but the occurrence of phytoplankton influences the seasonal variation of $\delta^{13} \mathrm{C}_{\mathrm{POM}}$ in lakes.

In this study, we have seasonally analysed the $\delta^{13} \mathrm{C}$ of different carbon species and related physical, chemical and biological factors in karst reservoirs from the Wujiang river basin. The main aim of our study was to discern which factors control variation in $\delta^{13} \mathrm{C}_{\mathrm{PHY}}$ and to better understand the mechanisms behind this control.

\section{METHODS}

The Wujiang river is a major hydropower source for China's massive West-to-East Power Transmission Project and a series of reservoirs have been constructed. The Wujiang river is a southern tributary of the Changjiang river, with a total length of $1037 \mathrm{~km}$ and a drainage area of 88,267 $\mathrm{km}^{2}$. It has a runoff of $53.4 \times 10^{9} \mathrm{~m}^{3}$ per year with a fall of $2124 \mathrm{~m}$ and it is the largest river in the Guizhou province. Investigations were carried out at eleven reservoirs (Tab. 1) and a total of 23 stations were selected (Fig. 1). Surface water samples (upper $0.5 \mathrm{~m}$ ) were collected in July and October 2007 and in January and April 2008, which represent summer, autumn, winter and spring, respectively. Water temperature (T) in site M4 was only measured in October and April. Site M5 in January could not be sampled due to a blocked access road.

Water temperature, dissolved oxygen, $\mathrm{pH}$ and $\mathrm{Chl} a$ were measured in situ using a calibrated water quality probe (model: YSI 6600; YSI Inc., Yellow Springs, OH,
USA). A small portion of each sample was stored for the analyses of total nitrogen (TN) and total phosphorus (TP). Both were determined spectrophotometrically (Unico UV2000; Unico, Dayton, NJ, USA) after alkaline potassium persulfate digestion (EPA, 1988). Samples for major cations and anions were filtered through $0.45 \mu \mathrm{m}$ filters. Samples for cation analysis were acidified to $\mathrm{pH} 2$ with ultrapurified $\mathrm{HNO}_{3}$. Major cations $\left(\mathrm{Ca}^{2+}, \mathrm{Mg}^{2+}, \mathrm{K}^{+}\right.$and $\mathrm{Na}^{+}$) were analysed by atomic absorption spectrometry (AAS, PE51002, America) and the anions $\left(\mathrm{SO}_{4}{ }^{2-}, \mathrm{NO}_{3}{ }^{-}\right.$, and $\mathrm{Cl}^{-}$) by high performance liquid chromatography (HP1100; Shimadzu Co., Kyoto, Japan). These major ions were used to calculate ionic strength. Alkalinity was titrated with $\mathrm{HCl}$ on the spot. $\mathrm{HCO}_{3}{ }^{-}$and dissolved $\mathrm{CO}_{2}$ were calculated based on alkalinity, $\mathrm{pH}$ and $\mathrm{T}$ with corrections of dissociation constants by temperature and ionic strength (Stumm and Morgan, 1981; Maberly, 1996; Barth and Veizer, 1999).

One and a half litres of surface water sample was preserved with Lugol's solution for quantitative analysis of phytoplankton. Phytoplankton for qualitative analysis was collected by a $64-\mu \mathrm{m}$ nylon mesh and preserved with formaldehyde solution ( $2 \%$ final concentration). The method by Zhang and Huang (1991) was used for taxon identification, counting and cell dimensions using a standard light microscope. The wet weight $\left(\mathrm{mg} \mathrm{L}^{-1}\right)$ of phytoplankton biomass was calculated according to its biovolume and cell density (Zhang and Huang, 1991).

Samples for $\delta^{13} \mathrm{C}$ of dissolved inorganic carbon $\left(\delta^{13} \mathrm{C}_{\mathrm{DIC}}\right)$ measurement were collected by filtering $100 \mathrm{~mL}$ of water through $0.45 \mu \mathrm{m}$ filters with a syringe into polyethylene vials. Then, a saturated $\mathrm{HgCl}_{2}$ solution was injected into the vials for sample preservation. The vials were immediately closed without headspace with caps and sealed with seal film (Parafilm). In the laboratory, the sample was injected into closed evacuated glass vessels con-

Tab. 1. Hydrographic parameters of the investigated reservoirs.

\begin{tabular}{|c|c|c|c|c|c|c|c|}
\hline \multirow[t]{2}{*}{ Reservoir } & $\begin{array}{l}\text { Drainage } \\
\text { area }\end{array}$ & $\begin{array}{c}\text { Average } \\
\text { flow }\end{array}$ & $\begin{array}{c}\text { Average } \\
\text { annual } \\
\text { precipitation }\end{array}$ & $\begin{array}{c}\text { Total } \\
\text { volume }\end{array}$ & $\begin{array}{c}\text { Height } \\
\text { of } \\
\text { dam }\end{array}$ & $\begin{array}{l}\text { Residence } \\
\text { time }\end{array}$ & \multirow[t]{2}{*}{$\begin{array}{l}\text { Impounded } \\
\text { time }\end{array}$} \\
\hline & $\left(\mathrm{km}^{2}\right)$ & $\left(\mathrm{m}^{3} / \mathrm{s}\right)$ & $(\mathrm{mm})$ & $\left(10^{8} \mathrm{~m}^{3}\right)$ & (m) & (d) & \\
\hline Hongjiadu & 9900 & 155 & 1191 & 49.47 & 182 & 369.4 & 2001 \\
\hline Dongfeng & 18,161 & 345 & 1118 & 8.64 & 162 & 28.9 & 1989 \\
\hline Suofengying & 21,862 & 427 & 1061 & 2.012 & 113 & 5.5 & 2002 \\
\hline Wujiangdu & 27,790 & 502 & 1124 & 23 & 165 & 53 & 1971 \\
\hline Hongfeng & 1596 & 29 & 1585 & 7.53 & 54 & 300.5 & 1959 \\
\hline Baihua & 1895 & 35 & 1362 & 2.21 & 50 & 73.1 & 1965 \\
\hline Xiuwen & 2145 & 39 & 1230 & 0.114 & 49 & 3.4 & 1961 \\
\hline Honglin & 2442 & 43 & 1169 & 0.0216 & 32 & 0.6 & 1967 \\
\hline Hongyan & 2792 & 48 & 1108 & 0.304 & 60 & 7.3 & 1974 \\
\hline Puding & 5871 & 123 & 1181 & 4.21 & 75 & 39.6 & 1989 \\
\hline Yizidu & 6425 & 152 & 1267 & 5.43 & 130 & 41.3 & 2001 \\
\hline
\end{tabular}


taining concentrated phosphoric acid and then heated at $50^{\circ} \mathrm{C}$ to extract $\mathrm{CO}_{2}$ (Atekwana and Krishnamurthy, 1998).

Samples for $\delta^{13} \mathrm{C}_{\mathrm{POM}}$ measurement were stored in high-density polyethylene bottles with screw closure (1500 mL, leak-proof). Bottles were rinsed three times prior to storage of water samples. Water samples were filtered through pre-combusted $\left(500^{\circ} \mathrm{C}, 5 \mathrm{~h}\right) 47 \mathrm{~mm}$ Whatman $\mathrm{GF} / \mathrm{F}$ glass fibre filter $(0.65 \mu \mathrm{m})$ (Whatman plc, Maidstone, UK) within 12 hours, stored at $-20^{\circ} \mathrm{C}$ and freeze-dried before analysis. Samples for $\delta^{13} \mathrm{C}_{\mathrm{PHY}}$ measurement were collected using a 64- $\mu$ m nylon mesh and immediately filtered with the same mesh and the phytoplankton obtained were transferred to vials and kept cool $\left(0-4^{\circ} \mathrm{C}\right)$ in the field and dried at $45^{\circ} \mathrm{C}$ in the laboratory within 24 hours. Particulate organic matter collected by the 64- $\mu \mathrm{m}$ net tow comprised major phytoplankton and some zooplankton. Since phytoplankton sustains herbivorous zooplankton production (Brett et al., 2009) and zooplankton shares $\delta^{13} \mathrm{C}$ similar to its source (Yoshii et al., 1999; Post, 2002), $\delta^{13} \mathrm{C}$ of the mixture collected here was considered as a surrogate of $\delta^{13} \mathrm{C}_{\mathrm{PHY}}$, although the mixture did not include total phytoplankton. Samples for $\delta^{13} C_{P O M}$ and $\delta^{13} \mathrm{C}_{\mathrm{PHY}}$ measurements were acidified with dilute hydrochloric acid and oven-dried overnight at $60^{\circ} \mathrm{C}$ just prior to carbon isotope determination. Particulate organic matter was converted into $\mathrm{CO}_{2}$ using the high-temperature $\left(850^{\circ} \mathrm{C}, 5 \mathrm{~h}\right)$ sealed-quartz tube combustion method with copper oxide as oxidant (Buchanan and Corcoran, 1959) as the low-temperature $\left(550^{\circ} \mathrm{C}, 1 \mathrm{~h}\right)$ combustion method can lead to large analytical uncertainty (Tao et al., 2001).

Carbon dioxide was cryogenically separated and its pressure and temperature were measured in a sensor (Edwards Barocel ${ }^{\circledR}$ 600; Edwards Ltd., Sanborn, NY, USA). The ${ }^{13} \mathrm{C} /{ }^{12} \mathrm{C}$ ratio of $\mathrm{CO}_{2}$ was determined on a dual-inlet isotope ratio mass spectrometer (MAT 252; Thermo Fisher Scientific Inc., Waltham, MA, USA). Carbon isotope data were normalised and are reported following the $\delta$ denotation of Craig (1953) relative to the Vienna Pee Dee Belemnite (VPDB). The total precision for concentration and $\delta^{13} \mathrm{C}$ analysis were better than $3 \%(1 \sigma)$ and

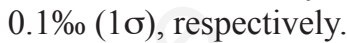

The $\delta^{13} \mathrm{C}$ of dissolved $\mathrm{CO}_{2}\left(\delta^{13} \mathrm{C}_{\mathrm{CO} 2}\right)$ was calculated

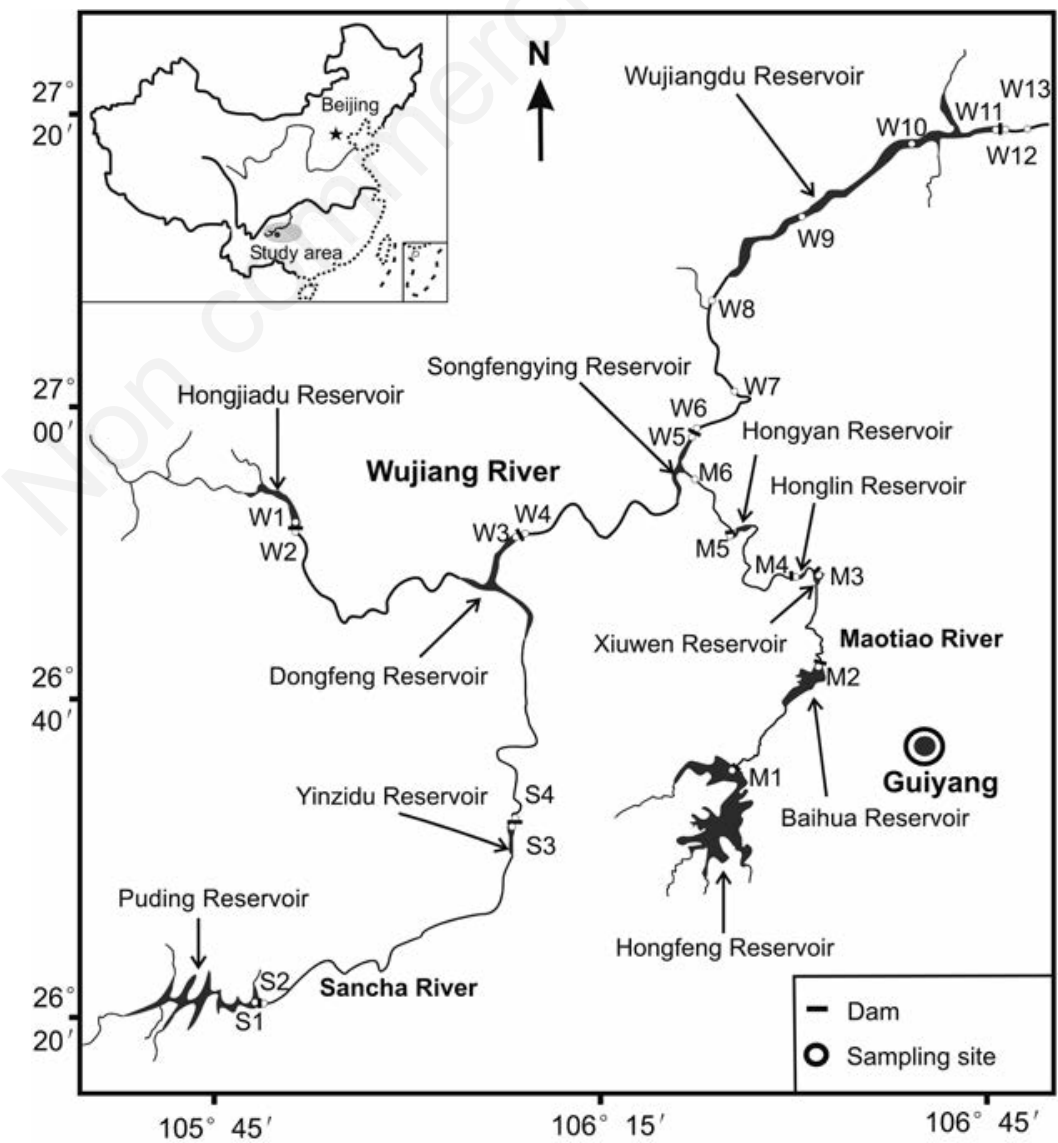

Fig. 1. Map showing sampling locations and numbers. 
from $\delta^{13} \mathrm{C}_{\mathrm{DIC}}$ and absolute $\mathrm{T}\left(\mathrm{T}_{\mathrm{K}}\right.$, in Kelvin) according to Mook et al. (1974) by using the equation provided by Rau et al. (1996):

$\delta^{13} \mathrm{C}_{\mathrm{CO} 2}=\delta^{13} \mathrm{C}_{\mathrm{DIC}}+23.644-9701.5 / \mathrm{T}_{\mathrm{K}}$

Carbon isotope fractionation was calculated relative to $\mathrm{CO}_{2}$ as a carbon source according to Freeman and Hayes (1992):

$\varepsilon_{\mathrm{p}}=\left(\delta^{13} \mathrm{C}_{\mathrm{CO} 2}-\delta^{13} \mathrm{C}_{\mathrm{PHY}}\right) /\left(1+\delta^{13} \mathrm{C}_{\mathrm{PHY}} / 1000\right)$

Pearson's correlation coefficient analysis and principal component analysis (PCA) were carried out using the software SPSS (version 11.5; SPSS Inc., Chicago, IL, USA). Multiple regression analysis was done with the Minitab 16 statistical software (Minitab Inc., Nerviano, Italy).

\section{RESULTS}

\section{Basic physical and chemical properties}

Major physical and chemical variables are listed in Tab. 2. The study area has a subtropical monsoon humid climate and water $\mathrm{T}$ displayed clear seasonal variations (Fig. 2). Water $\mathrm{T}$ increased from January and reached a maximum value in July. Amplitude of water T within seasons was larger than within reservoirs (Fig. 3). $\mathrm{pH}$ had a similar fluctuation pattern to water $\mathrm{T}$ and therefore showed a significant positive correlation with it (Tab. 3). Total phosphorus showed a larger fluctuation within reservoirs than within seasons. Average value of TN was about 100 times larger than that of TP. However, TN showed less temporal and spatial variation than TP.

$\mathrm{HCO}_{3}{ }^{-}$and $\mathrm{SO}_{4}{ }^{2-}$ were the dominant anions, while $\mathrm{Ca}^{2+}$ and $\mathrm{Mg}^{2+}$ were the dominant cations in the river water (Tab. 2). This is because the Wujiang river basin is mainly underlain by Permian and Triassic carbonate rocks and the river water chemistry is controlled by carbonate dissolution by both carbonic and sulfuric acid (Liu, 2007). Dissolved $\mathrm{CO}_{2}$ displayed a larger fluctuation in concentration than $\mathrm{HCO}_{3}^{-}$. Still, it showed a significant positive correlation with $\mathrm{HCO}_{3}^{-}$and both displayed large variations within seasons and reservoirs (Figs. 2 and 3).

\section{Phytoplankton}

In these reservoirs there were four main algal groups: Chlorophyta, Dinophyta, Bacillariophyta, and Cyanophyta (Fig. 4). Phytoplankton showed a clear different variation in species composition within reservoirs and seasons. Chlorophyta and Dinophyta were dominant in July. Bacillariophyta increased from October and dominated in January and April. In the eutrophic reservoirs Hongfeng and Baihua, the dominant algae were Cyanophyta and Chloro-

Tab. 2. Averages and range of major biogeochemical variables in the studied reservoirs.

\begin{tabular}{|c|c|c|c|c|}
\hline & Average & SD & $\operatorname{Max}$ & Min \\
\hline $\mathrm{T}\left({ }^{\circ} \mathrm{C}\right)$ & 18.10 & 4.79 & 30.00 & 9.68 \\
\hline $\mathrm{pH}$ & $7.98^{*}$ & 9.37 & 7.39 & \\
\hline $\mathrm{Ca}\left(\mathrm{mmol} \mathrm{L}^{-1}\right)$ & 1.44 & 0.16 & 1.89 & 0.89 \\
\hline $\mathrm{Mg}\left(\mathrm{mmol} \mathrm{L}^{-1}\right)$ & 0.45 & 0.10 & 0.67 & 0.25 \\
\hline $\mathrm{Na}\left(\mathrm{mmol} \mathrm{L}^{-1}\right)$ & 0.27 & 0.14 & 0.71 & 0.12 \\
\hline $\mathrm{K}\left(\mathrm{mmol} \mathrm{L}^{-1}\right)$ & 0.05 & 0.02 & 0.16 & 0.03 \\
\hline $\mathrm{HCO}_{3}\left(\mathrm{mmol} \mathrm{L}^{-1}\right)$ & 2.28 & 0.32 & 2.96 & 1.14 \\
\hline $\mathrm{SO}_{4}\left(\mathrm{mmol} \mathrm{L}^{-1}\right)$ & 0.94 & 0.19 & 1.58 & 0.59 \\
\hline $\mathrm{NO}_{3}\left(\mathrm{mmol} \mathrm{L}^{-1}\right)$ & 0.17 & 0.06 & 0.29 & 0.01 \\
\hline $\mathrm{Cl}\left(\mathrm{mmol} \mathrm{L}^{-1}\right)$ & 0.12 & 0.06 & 0.35 & 0.06 \\
\hline $\mathrm{TN}\left(\mathrm{mmol} \mathrm{L}^{-1}\right)$ & 0.22 & 0.06 & 0.39 & 0.05 \\
\hline $\mathrm{TP}(\mu \mathrm{mol} \mathrm{L}-1)$ & 1.81 & 1.77 & 10 & 0.01 \\
\hline $\mathrm{CO}_{2}(\mu \mathrm{mol} \mathrm{L}-1)$ & 56.7 & 42.4 & 207.6 & 1.0 \\
\hline Chl $a\left(\mu \mathrm{g} \mathrm{L}^{-1}\right)$ & 4.4 & 11.8 & 80.0 & 0.1 \\
\hline T-PHY $\left(\mathrm{mg} \mathrm{L}^{-1}\right)$ & 7.02 & 10.2 & 53.5 & 1.1 \\
\hline CHLO $\left(\mathrm{mg} \mathrm{L}^{-1}\right)$ & 3.38 & 7.03 & 49.70 & 0.00 \\
\hline BACI $\left(\mathrm{mg} \mathrm{L}^{-1}\right)$ & 2.19 & 2.59 & 14.80 & 0.13 \\
\hline CYAN (mg L $\left.{ }^{-1}\right)$ & 0.42 & 2.70 & 24.7 & 0.00 \\
\hline DINO $\left(\mathrm{mg} \mathrm{L}^{-1}\right)$ & 1.03 & 3.95 & 27.5 & 0.00 \\
\hline$\delta^{13} \mathrm{C}_{\mathrm{DIC}}(\%)$ & -8.2 & 1.26 & -3.27 & -9.99 \\
\hline$\delta^{13} \mathrm{C}_{\text {РОМ }}(\% 0)$ & -29.5 & 2.67 & -19.6 & -34.5 \\
\hline$\delta^{13} \mathrm{C}_{\mathrm{PHY}}(\% o)$ & -30.8 & 4.34 & -15.1 & -39.2 \\
\hline$\varepsilon_{\mathrm{p}}(\%)$ & 13.24 & 4.04 & 20.90 & 2.06 \\
\hline
\end{tabular}

"Geometric mean. T, temperature; $\mathrm{Ca}$, calcium; $\mathrm{Mg}$, magnesium; $\mathrm{Na}$, sodium; $\mathrm{K}$, potassium; $\mathrm{HCO}_{3}$, hydrogen carbonate; $\mathrm{SO}_{4}$, sulfate; $\mathrm{NO}_{3}$, nitrate; $\mathrm{Cl}$, chlorine; TN, total nitrogen; TP, total phosphorus; $\mathrm{CO}_{2}$, dissolved $\mathrm{CO}_{2} ; \mathrm{Chl}$ a, chlorophyll a; T-PHY, total phytoplankton biomass; CHLO, Chlorophyta; BACI, Bacillariophyta; CYAN, Cyanophyta; DINO, Dinophyta; $\delta^{13} C_{D I C}$ carbon stable isotope composition of dissolved inorganic carbon; $\delta^{13} C_{P O M}$, particulate organic matter; $\delta^{13} C_{P H}$, carbon stable isotope composition of phytoplankton; $\varepsilon_{p}$, carbon isotope fractionation. 

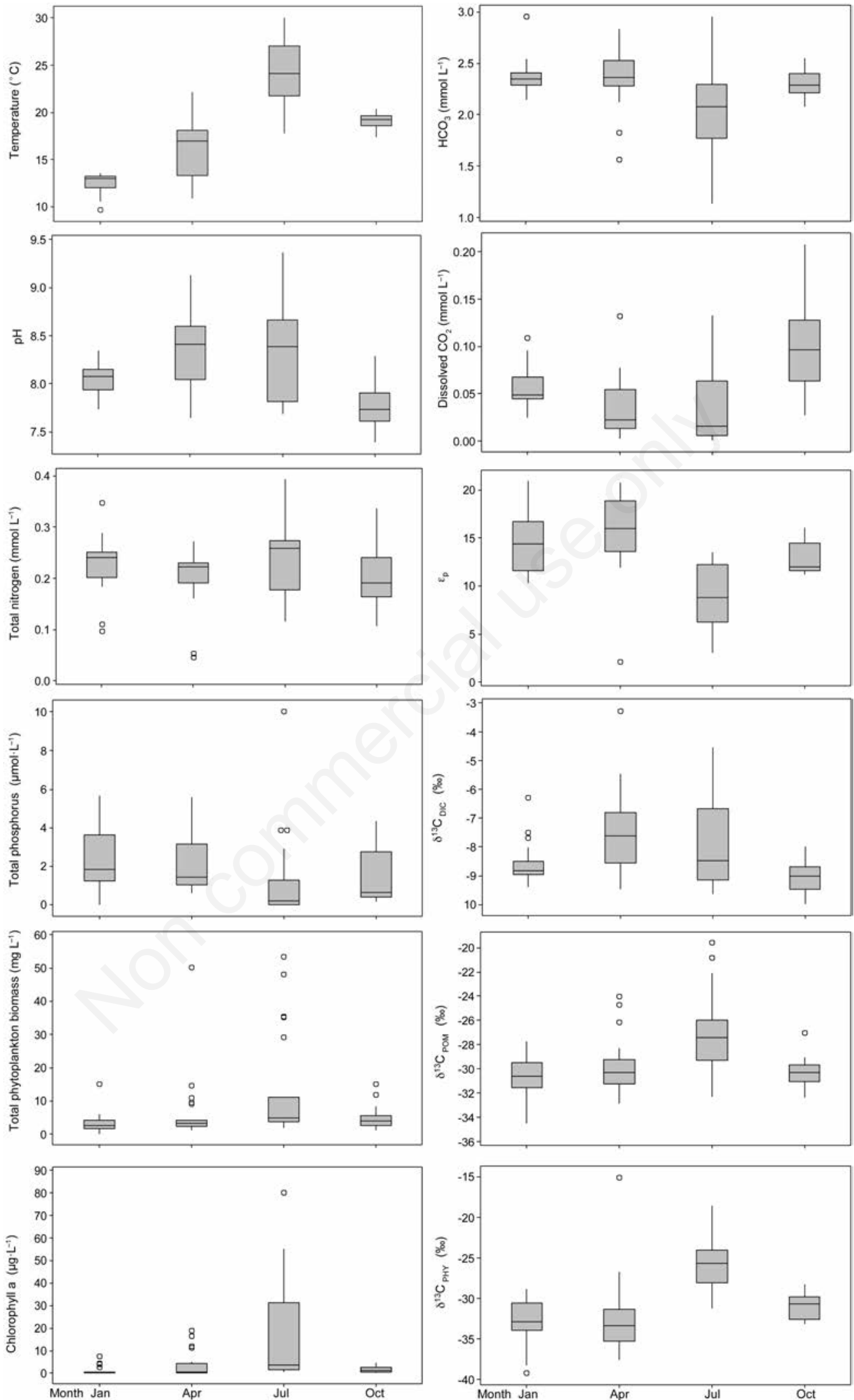

Fig. 2. Box plots of physical, chemical, and biological variables in different seasons. Box boundaries indicate the $25^{\text {th }}$ and $75^{\text {th }}$ percentiles; whiskers extend to a maximum of 1.5 times the inter-quartile range. The inner horizontal line is the median, while circles indicate outliers. 
phyta, and in the others, the dominant algae were Bacillariophyta and Chlorophyta. Dinophyta was only abundant in July 2007. Different reservoir showed different phytoplankton community structure: for example, in April 2008 the dominant algae in Hongfeng reservoir were Chlorophyta and those in Wujiangdu reservoir were Bacillariophyta.

Phytoplankton biomass was significantly correlated with $\mathrm{Chl} a$ concentration ( $\mathrm{R}=0.802, \mathrm{P}<0.001)$. Phytoplankton biomass also showed a large variation within seasons and reservoirs. Chl $a$ was significantly correlated with TP (Tab. 3), suggesting that $P$ was a limiting factor for phytoplankton growth in these reservoirs. Temperature was also highly significantly correlated with $\mathrm{Chl} a$, indicating that increasing water $T$ could stimulate algal growth.

\section{Carbon stable isotope composition of different carbon species}

The $\delta^{13} \mathrm{C}_{\mathrm{DIC}}, \delta^{13} \mathrm{C}_{\mathrm{POM}}$ and $\delta^{13} \mathrm{C}_{\mathrm{PHY}}$ values for all samples are listed in Tab. 2. The seasonal fluctuation of $\delta^{13} \mathrm{C}_{\mathrm{PHY}}$ was comparable to that of $\delta^{13} \mathrm{C}_{\mathrm{POM}}$ and larger than that of $\delta^{13} \mathrm{C}_{\mathrm{DIC}}$ (Fig. 2). The average $\delta^{13} \mathrm{C}_{\mathrm{PHY}}$ value was $-25.7 \%$ in July 2007 and $-33.1 \%$ in January 2008; however, the average $\delta^{13} \mathrm{C}_{\text {DIC }}$ value was $-7.8 \%$ in July 2007 and $-8.6 \%$ in January 2008 . The $\delta^{13} \mathrm{C}_{\mathrm{PHY}}$ value differed significantly among reservoirs (Fig. 3), being $-15.1 \%$ in the Hongfeng reservoir and $-31.7 \%$ in the Wujiangdu reservoir in April 2008. The carbon stable isotope composition of phytoplankton showed a significant relationship with $\delta^{13} \mathrm{C}_{\mathrm{POM}}$ (Tab. 3), suggesting that POM was mainly derived from phytoplankton in these reservoirs. Soil organic matter and phytoplankton are the possible contributors of riverine POM; however, after damming a river to produce a reservoir, a riverine heterotrophic ecosystem may be transformed into an autotrophic one (Wetzel, 2001), and phytoplankton becomes the dominant contributor of POM.

Principal component analysis was conducted for the whole dataset and each season, respectively (Fig. 5). The first three principal components with an eigenvalue more than 1 were extracted. For the whole dataset, the principal components 1,2, and 3 represented 55.7, 17.1 and 9.3\% of the total variance, respectively (Fig. 5a). The first component ( $\mathrm{PC} 1$ ) showed a positive correlation with $\mathrm{T}, \mathrm{pH}$, $\delta^{13} C_{\text {DIC }}, \delta^{13} C_{\text {POM }}, \delta^{13} C_{\text {PHY }}$, and algal biomass (total phytoplankton, Chlorophyta, Dinophyta, and Chl a), respectively ( $\mathrm{R}>0.803$; Fig. $5 \mathrm{a}$ ), suggesting that they are the coupling factors. The results of PCA in relation to $\delta^{13} \mathrm{C}_{\mathrm{PHY}}$ from each season differed from one another (Figs. 5b-e), indicating that the factors controlling $\delta^{13} \mathrm{C}_{\mathrm{PHY}}$ were different in different seasons.

Multiple regression analysis was conducted for some variables (Tab. 4). According to this analysis, $\mathrm{T}, \mathrm{HCO}_{3}^{-}$, contribution of Bacillariophyta to total phytoplankton (CBTP) (\%), and total phytoplankton biomass (T-PHY) were the main four factors controlling $\delta^{13} \mathrm{C}_{\mathrm{PHY}}$.
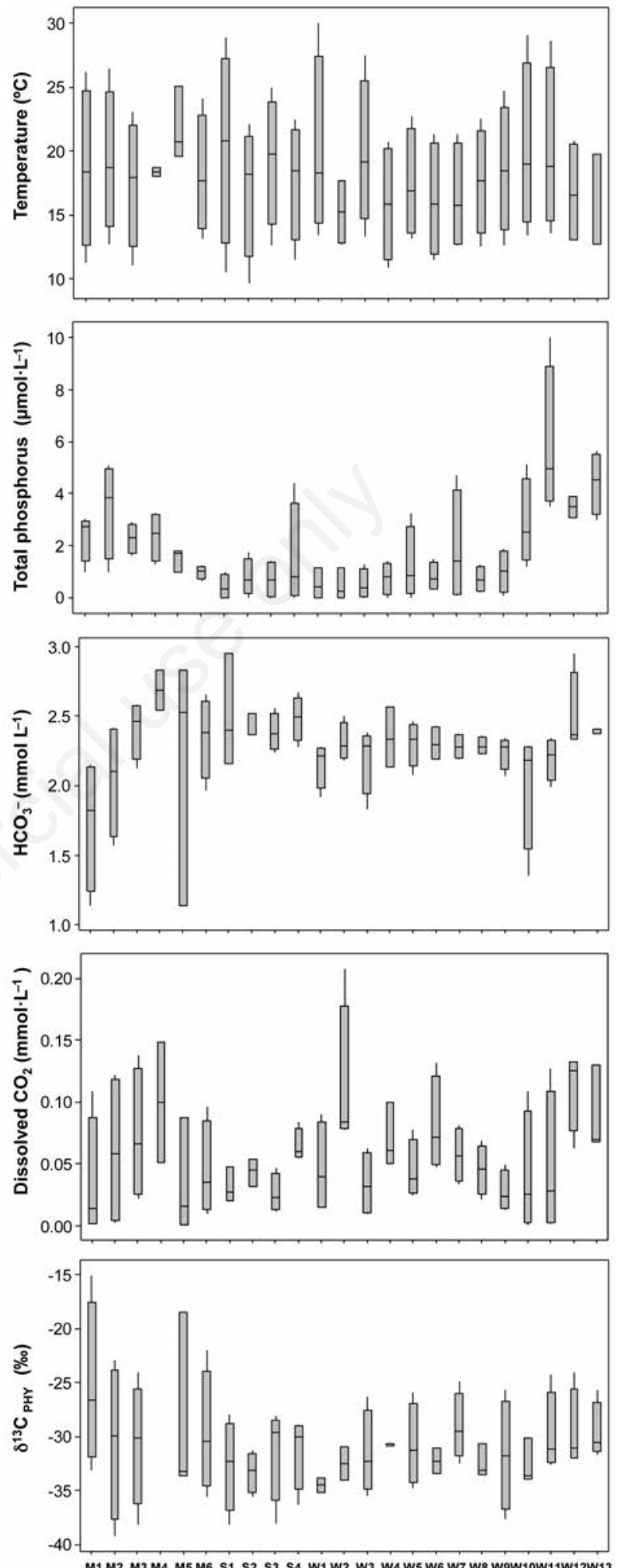

Fig. 3. Box plots of physical, chemical, and biological variables in different reservoirs. Box boundaries indicate the $25^{\text {th }}$ and $75^{\text {th }}$ percentiles; whiskers extend to a maximum of 1.5 times the inter-quartile range. The inner horizontal line is the median, while circles indicate outliers (see Fig. 1 for site names). 
Tab. 3. Results of Pearson's correlation coefficient analysis.

\begin{tabular}{|c|c|c|c|c|c|c|c|c|c|c|c|c|c|c|}
\hline & $\mathrm{T}$ & $\mathrm{pH}$ & $\mathrm{CO}_{2}$ & $\mathrm{HCO}_{3}^{-}$ & $\mathrm{TN}$ & $\mathrm{TP}$ & Chl $a$ & T-PHY & CHLO & BACI & CYAN & DINO & $\delta^{13} \mathrm{C}_{\mathrm{DIC}} \delta^{13} \mathrm{C}_{\mathrm{POM}}$ & $\delta^{13} \mathrm{C}_{\mathrm{PHY}}$ \\
\hline $\mathrm{pH}$ & $0.336^{* *}$ & & & & & & & & & & & & & \\
\hline $\mathrm{CO}_{2}$ & -0.212 & $-0.874^{* *}$ & & & & & & & & & & & & \\
\hline $\mathrm{HCO}_{3}^{-}$ & $-0.501^{* *}$ & $-0.537^{* *}$ & $0.351^{* *}$ & & & & & & & & & & & \\
\hline $\mathrm{TN}$ & 0.078 & -0.137 & 0.059 & 0.107 & & & & & & & & & & \\
\hline $\mathrm{TP}$ & $-0.220^{*}$ & 0.142 & 0.048 & 0.025 & -0.205 & & & & & & & & & \\
\hline Chl $a$ & $0.461^{* *}$ & $0.593^{* *}$ & $-0.324^{* *}$ & $-0.478^{* *}$ & 0.120 & $0.454^{*}$ & & & & & & & & \\
\hline T-PHY & $0.421^{* *}$ & $0.661^{* *}$ & $-0.384^{* *}$ & $-0.656^{* *}$ & $-0.245^{*}$ & ${ }^{* *} 0.206$ & $0.802^{* *}$ & & & & & & & \\
\hline CHLO & $0.331^{* *}$ & $0.552^{* *}$ & $-0.310^{* *}$ & $-0.555^{* *}$ & $-0.237^{*}$ & ${ }^{*} 0.259^{*}$ & $0.636^{* *}$ & ${ }^{*} 0.883^{* *}$ & & & & & & \\
\hline BACI & -0.100 & 0.151 & -0.135 & 0.172 & -0.093 & 0.004 & 0.044 & 0.108 & -0.141 & & & & & \\
\hline CYAN & 0.189 & 0.243 & -0.136 & $-0.396^{* *}$ & -0.234 & -0.017 & -0.021 & $0.305^{* *}$ & 0.076 & -0.055 & & & & \\
\hline DINO & $0.495^{* *}$ & $0.629^{* *}$ & $-0.406^{* *}$ & $-0.732^{* *}$ & 0.048 & 0.145 & $0.874^{* *}$ & ${ }^{*} 0.910^{* *}$ & $0.798^{* *}$ & -0.171 & -0.050 & & & \\
\hline$\delta^{13} \mathrm{C}_{\mathrm{DIC}}$ & $0.370^{* *}$ & $0.810^{* *}$ & $-0.704^{* *}$ & $-0.515^{* *}$ & -0.149 & -0.019 & $0.358^{* *}$ & ${ }^{*} 0.583^{* *}$ & $0.543^{* *}$ & $0.207^{*}$ & -0.242 & $0.435^{* *}$ & & \\
\hline$\delta^{13} \mathrm{C}_{\mathrm{POM}}$ & $0.463^{* *}$ & $0.499^{* *}$ & $-0.301^{* *}$ & $-0.614^{* *}$ & -0.038 & 0.209 & $0.608^{* *}$ & ${ }^{*} 0.634^{* *}$ & $0.573^{* *}$ & $-0.261^{*}$ & $0.293^{*}$ & $0.733^{* *}$ & $0.333^{* *}$ & \\
\hline$\delta^{13} \mathrm{C}_{\mathrm{PHY}}$ & $0.572^{* *}$ & $0.349^{* *}$ & -0.190 & $-0.630^{* *}$ & -0.075 & 0.045 & $0.392^{* *}$ & ${ }^{*} 0.592^{* *}$ & $0.625^{* *}$ & $-0.318^{* *}$ & 0.126 & $0.645^{* *}$ & $0.337^{* *} 0.769^{* *}$ & \\
\hline$\varepsilon p$ & $0.419^{* *}$ & -0.087 & -0.040 & $0.499^{* *}$ & 0.003 & -0.102 & $-0.276^{*}$ & $-0.413^{* *}$ & $-0.479^{* *}$ & $0.423^{* *}$ & -0.022 & $-0.568^{* *}$ & $-0.015-0.696^{* *}$ & $-0.938^{* *}$ \\
\hline
\end{tabular}

${ }^{* *}$ Correlation is significant at the 0.01 level (2-tailed); "correlation is significant at the 0.05 level (2-tailed). $\mathrm{CO}_{2}$, dissolved $\mathrm{CO}_{2} ; \mathrm{HCO}_{3}$, hydrogen carbonate; TN, total nitrogen; TP, total phosphorus; Chl a, chlorophyll a; T-PHY, total phytoplankton biomass; CHLO, Chlorophyta; BACI, Bacillariophyta; CYAN, Cyanophyta; DINO, Dinophyta; $\delta^{13} C_{D I C}$, carbon stable isotope composition of dissolved inorganic carbon; $\delta^{I 3} C_{P O M}$, particulate organic matter; $\delta^{13} C_{P H Y}$, carbon stable isotope composition of phytoplankton; $\varepsilon_{p}$, carbon isotope fractionation.
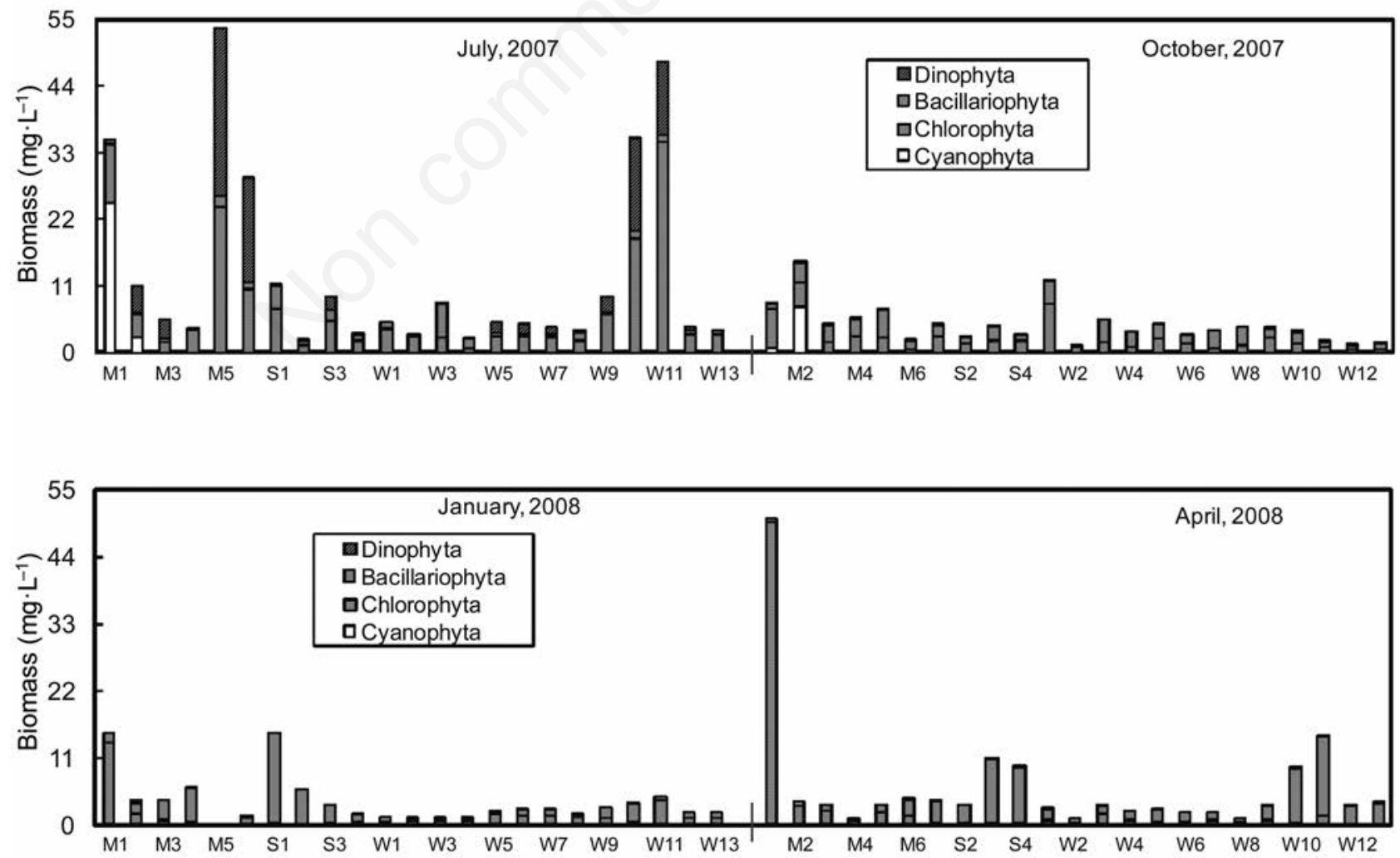

Fig. 4. Seasonal variation of phytoplankton species composition and biomass (see Fig. 1 for site names). 

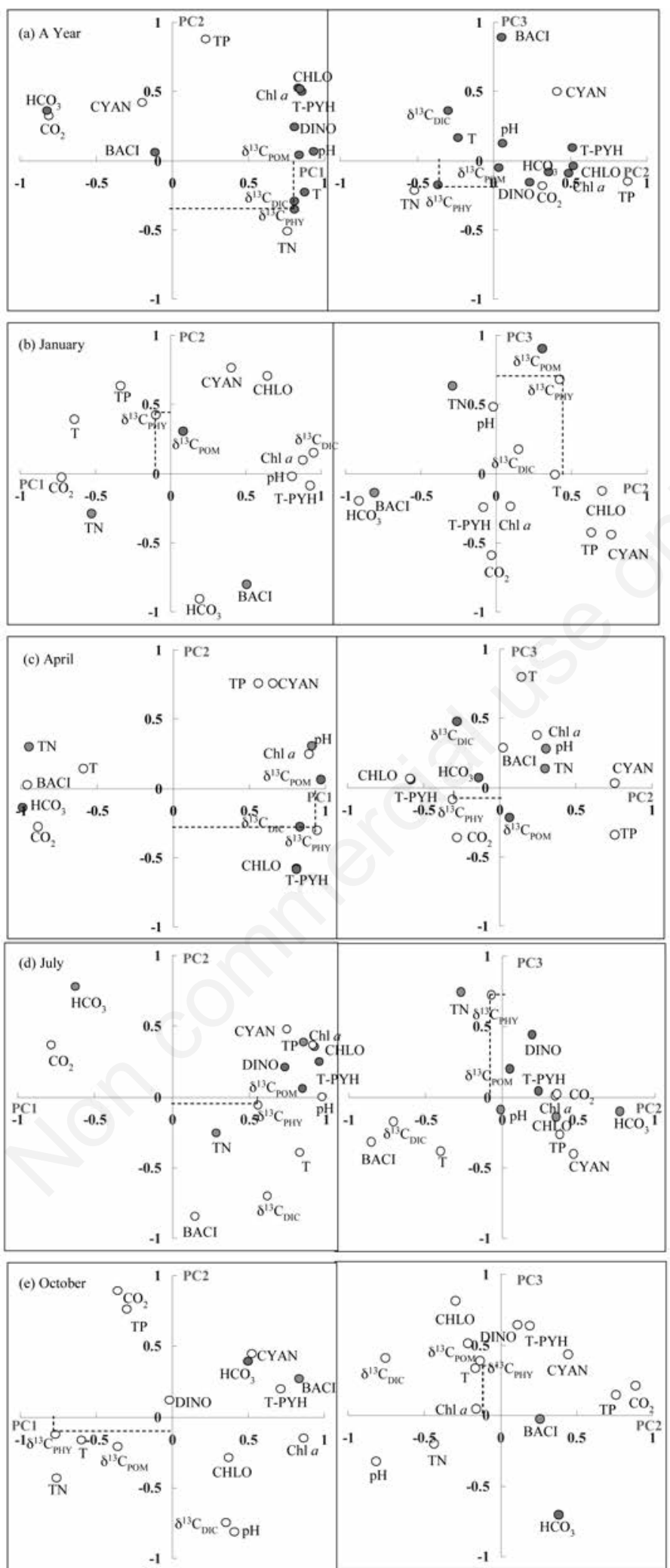

Fig. 5. Scatter plots of principal component 1 (PC1) versus principal component 2 (PC2) and PC2 vs 3 (PC3) in all the datasets and each season, respectively. Black circles mean that correlation with carbon stable isotope composition of phytoplankton $\left(\delta^{13} \mathrm{C}_{\mathrm{PHY}}\right)$ is significant at the 0.01 level (2-tailed); grey circles mean that correlation with $\delta^{13} \mathrm{C}_{\mathrm{PHY}}$ is significant at the 0.05 level (2-tailed); blank circles mean that correlation with $\delta^{13} \mathrm{C}_{\mathrm{PHY}}$ is not significant. 


\section{DISCUSSION}

\section{Effect of temperature on the carbon stable isotope composition of phytoplankton}

Sackett et al. (1965) first reported the relationship between phytoplankton $\delta^{13} \mathrm{C}$ and sea surface $\mathrm{T}$ and this has been extended in subsequent work (Wong and Sackett, 1978; Hinga et al., 1994). Variation of T induces a change of algal physiology and biochemistry, such as growth rate and carboxylase activity (Li et al., 1984; Wang et al., 2008) and therefore results in a change in algal $\delta^{13} \mathrm{C}$. In this study, we found that $\delta^{13} \mathrm{C}_{\mathrm{PHY}}$ increased with $\mathrm{T}$, and this result is consistent with another experimental study (Johnston, 1996). On the basis of the correlation analyses and PCA, we concluded that, as T increased, phytoplankton assimilated more DIC and biomass also increased. In turn, this led to an increase of $\delta^{13} \mathrm{C}_{\mathrm{PHY}}$ and $\delta^{13} \mathrm{C}_{\mathrm{DIC}}$, accompanied by the increase of $\mathrm{pH}$. Undoubtedly, $\mathrm{T}$ is an important controlling factor on $\delta^{13} \mathrm{C}_{\mathrm{PHY}}$, though the variation of $\delta^{13} \mathrm{C}_{\mathrm{PHY}}$ cannot be explained by the thermal effect alone. Compared to $\mathrm{T}, \mathrm{pH}$ was passively changed by seasonal changes in biological activity (i.e. photosynthesis and respiration), which was triggered by seasonal change of $\mathrm{T}$ as mentioned above. Furthermore, increasing of $\mathrm{T}$ reduced the solubility of $\mathrm{CO}_{2}$, which may also have affected $\mathrm{pH}$, as the temperature dependence of the carbonate dissociation constants and the high concentrations of dissolved $\mathrm{CO}_{2}$ due to respiration in the bottom water of the reservoir may have led to the low $\mathrm{pH}$ value of the release water (Wang et al., 2008, 2011). Therefore, $\mathrm{pH}$ was not considered as an important direct controlling factor on $\delta^{13} \mathrm{C}_{\mathrm{PHY}}$ in these reservoirs, though it also showed a significant correlation with $\delta^{13} \mathrm{C}_{\mathrm{PHY}}$ (Tab. 3).

\section{Effect of different carbon sources on the carbon stable isotope composition of phytoplankton}

Both $\mathrm{HCO}_{3}^{-}$and $\mathrm{CO}_{2}$ can be the inorganic carbon source for phytoplankton growth (Burkhardt et al., 1999; Cassar et al., 2004). An equilibrium isotope effect in the hydration/dehydration reactions between $\mathrm{HCO}_{3}{ }^{-}$and $\mathrm{CO}_{2}$ concentrates isotopically light carbon in the $\mathrm{CO}_{2}$ in a tem- perature-sensitive manner, with $\delta^{13} \mathrm{C}$ of $\mathrm{CO}_{2}$ lower than those of $\mathrm{HCO}_{3}{ }^{-}$by $12 \%$ at $0^{\circ} \mathrm{C}$ and $8.4 \%$ at $30^{\circ} \mathrm{C}$ (Mook et al., 1974). $\mathrm{HCO}_{3}{ }^{-}$dominated $\mathrm{DIC}$ due to $\mathrm{pH}$ value greater than 8 in these reservoirs and $\delta^{13} \mathrm{C}_{\text {of }} \mathrm{HCO}_{3}{ }^{-}$was therefore considered as $\delta^{13} \mathrm{C}_{\text {DIC }}$ with an average value of about $-8 \%$ o (Tab. 2). The average $\delta^{13} \mathrm{C}_{\text {of }} \mathrm{CO}_{2}$ was $-17.9 \%$ o according to equation 1 (eq. 1) which is $9.7 \%$ lower than average $\delta^{13} \mathrm{C}_{\text {of }} \mathrm{HCO}_{3}{ }^{-}$. Therefore, the shift from $\mathrm{CO}_{2}$ to $\mathrm{HCO}_{3}{ }^{-}$as inorganic carbon source can strongly affect the $\delta^{13} \mathrm{C}_{\mathrm{PHY}}$ value.

Culture experiment demonstrated that marine diatom Phaeodactylum tricomutum may obtain inorganic carbon via active transport of $\mathrm{HCO}_{3}{ }^{-}$and/or $\mathrm{CO}_{2}$ when the concentration of aqueous $\mathrm{CO}_{2}$ is $10 \mu \mathrm{mol} \mathrm{kg}{ }^{-1}$ or less (Laws et al., 1995). Our results also found that, when the concentration of dissolved $\mathrm{CO}_{2}$ was less than $10 \mu \mathrm{mol} \mathrm{L}{ }^{-1}$, the availability of aqueous $\mathrm{CO}_{2}$ was not enough to support phytoplankton growth, so phytoplankton began to use $\mathrm{HCO}_{3}^{-}$as inorganic carbon source and this finally resulted in a substantial increase of $\delta^{13} \mathrm{C}_{\mathrm{PHY}}$ (Fig. 6). In the southern ocean, approximately half of the DIC uptake observed was attributable to direct $\mathrm{HCO}_{3}^{-}$uptake by phytoplankton (Cassar et al., 2004). Aqueous $\mathrm{CO}_{2}$ concentrations in the ocean typically fall in the range $10-20 \mu \mathrm{mol} \mathrm{kg}^{-1}$ (Rau et al., 1992), while dissolved $\mathrm{CO}_{2}$ concentrations in this study were usually more than $10 \mu \mathrm{mol} \mathrm{L}^{-1}$ with the average value of $56.7 \mu \mathrm{mol} \mathrm{L}^{-1}$ and the concentrations of $\mathrm{HCO}_{3}^{-}$were only found to decrease sharply when the concentrations of dissolved $\mathrm{CO}_{2}$ were less than $10 \mu \mathrm{mol} \mathrm{L}{ }^{-1}$.

The average partial pressure of $\mathrm{CO}_{2}(1588 \mu \mathrm{atm}$, equal to the average dissolved $\mathrm{CO}_{2}$ concentration of $56.7 \mu \mathrm{mol}$ $\left.\mathrm{L}^{-1}\right)$ was higher in these reservoirs than in air $(380 \mu \mathrm{atm})$, suggesting that the dissolved $\mathrm{CO}_{2}$ was mainly from $\mathrm{HCO}_{3}{ }^{-}$instead of atmosphere. Dissolved $\mathrm{CO}_{2}$ did not show a significant correlation with $\delta^{13} \mathrm{C}_{\mathrm{PHY}}$, but strongly correlated with $\mathrm{HCO}_{3}{ }^{-}$and $\mathrm{pH}$ (Tab. 3). This implies that the depletion of $\mathrm{CO}_{2}$ by algal uptake was quickly compensated by $\mathrm{HCO}_{3}^{-}$in the growing seasons. The concentration of $\mathrm{HCO}_{3}^{-}$decreased during periods of high algal biomass and the residual inorganic carbon pool became increasingly enriched in ${ }^{13} \mathrm{C}$, leading to further enrichment in algal ${ }^{13} \mathrm{C}$. This explains why $\delta^{13} \mathrm{C}_{\mathrm{PHY}}$ showed a signifi-

Tab. 4. Results of multiple regression analysis of variables concerned. Coefficient and standard error of the coefficient are listed in parenthesis.

\begin{tabular}{|c|c|c|c|c|c|c|c|c|c|c|}
\hline Variable & Constant & Temp & $\mathrm{pH}$ & TP & $\mathrm{SO}_{4}$ & $\mathrm{HCO}_{3}$ & CBTP & T-PHY & Adj $R^{2}$ & $\mathrm{P}$ \\
\hline$\delta^{13} C_{\mathrm{PHY}}$ & $-24.4(3.9)$ & $0.20(0.08)$ & & & & $-3.52(1.39)$ & $-0.053(0.012)$ & $0.086(0.039)$ & $62.2 \%$ & 0.000 \\
\hline $\mathrm{HCO}_{3}$ & $3.43(0.56)$ & $-0.013(0.006)$ & $-0.15(0.07)$ & & $0.44(0.13)$ & & & $-0.013(0.003)$ & $54.6 \%$ & 0.000 \\
\hline $\mathrm{CO}_{2}$ & $0.01(0.04)$ & & & & & & $0.024(0.018)$ & $-0.001(0.0005)$ & $14.4 \%$ & 0.001 \\
\hline T-PHY & $-110.3(14.84)$ & $0.60(0.18)$ & $12.85(1.95)$ & $1.13(0.47)$ & & & & & $50.5 \%$ & 0.000 \\
\hline
\end{tabular}

$T P$, total phosphorus; $\mathrm{SO}_{4}$, sulfate; $\mathrm{HCO}_{3}$, hydrogen carbonate; $\mathrm{CBTP}$, contribution of Bacillariophyta to total phytoplankton; T-PHY, total phytoplankton biomass; Adj $R^{2}$, adjusted R-squared; $\delta^{13} C_{P H Y}$, carbon stable isotope composition of phytoplankton; $\mathrm{CO}_{2}$, dissolved $\mathrm{CO}_{2}$. 
cant positive correlation with $\delta^{13} \mathrm{C}_{\mathrm{DIC}}$ and a negative correlation with $\mathrm{HCO}_{3}^{-}$concentration.

\section{Effect of taxonomic difference on the carbon stable isotope composition of phytoplankton}

Taxonomic differences in the carbon concentrating mechanism (CCM) and cell morphology may account for the observed differences in $\varepsilon_{\mathrm{p}}$ responses (Laws et al., 1995; Popp et al., 1998; Burkhardt et al., 1999). Therefore, as for phytoplankton from the same sample, different algal groups have different $\delta^{13} \mathrm{C}$. In this study, $\delta^{13} \mathrm{C}_{\mathrm{PHY}}$ tended to decrease with the increase of Bacillariophyta (Fig. 7), suggesting that Bacillariophyta had lower $\delta^{13} \mathrm{C}$ values than other algal groups. Low $\delta^{13} \mathrm{C}$ value of Bacillariophyta has been reported at about $-31 \%$ in lakes (Zohary et al., 1994; Jones et al., 1998; Vuorio et al., 2006). In this study $\delta^{13} \mathrm{C}_{\mathrm{PHY}}$ had an average value of about $-34 \%$ when the phytoplankotn
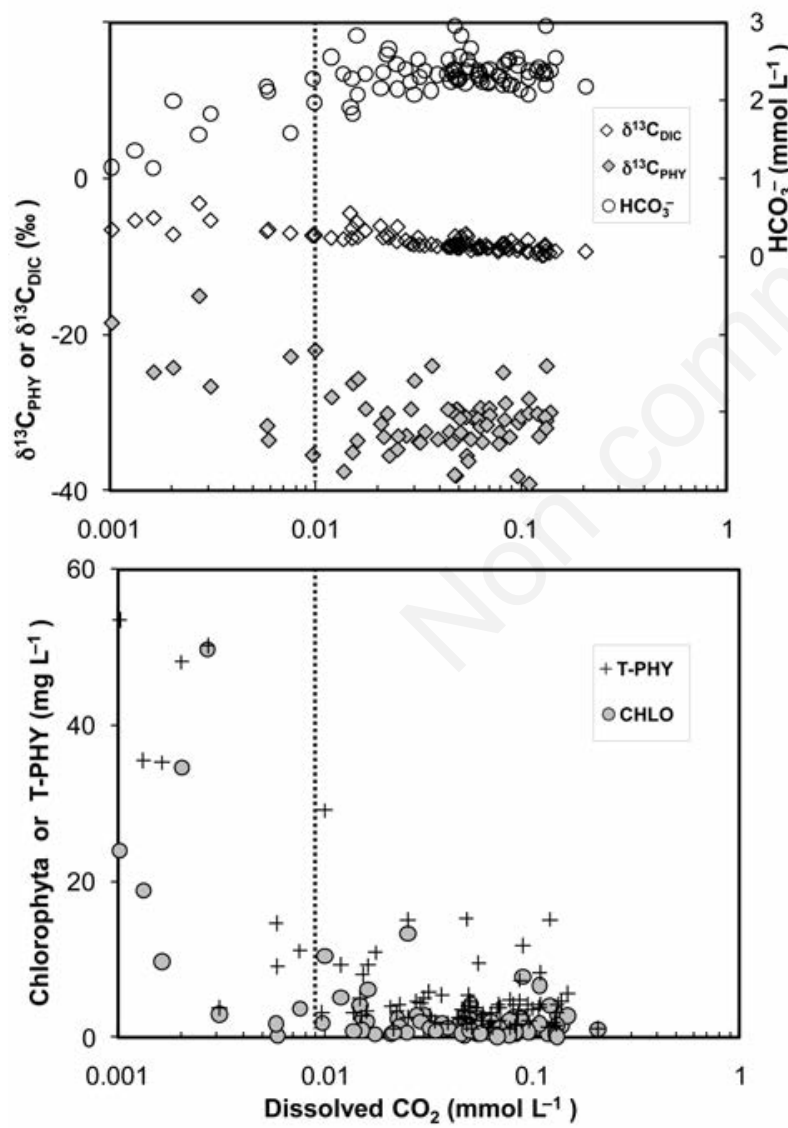

Fig. 6. Scatter plots of dissolved $\mathrm{CO}_{2} v s$ each related factor. Labels used are: $\delta^{13} \mathrm{C}_{\mathrm{DIC}}$, carbon stable isotope composition of dissolved inorganic carbon; $\delta^{13} \mathrm{C}_{\mathrm{PHY}}$, carbon stable isotope composition of phytoplankton; T-PYH, total phytoplankton biomass; CHLO, Chlorophyta. community was dominated by Bacillariophyta $(>90 \%$, Fig. 7). Bacillariophyta were abundant in January and April, and the low water $\mathrm{T}$ in these seasons may have decreased the growth rate of Bacillariophyta. This low growth rate can lead to low $\delta^{13} \mathrm{C}$ in Bacillariophyta (Laws et al., 1995; Fry, 1996). However, there is a lack of convincing evidence to explain why Bacillariophyta have low $\delta^{13} \mathrm{C}$ values in freshwater ecosystem.

The value of $\delta^{13} \mathrm{C}_{\mathrm{PHY}}$ increased with the increase of abundance of Chlorophyta and Dinophyta, which were the dominant algal groups in July (Fig. 4). Chlorophyta and Cyanophyta can use $\mathrm{HCO}_{3}{ }^{-}$directly or indirectly by extracellular conversion to $\mathrm{CO}_{2}$ catalysed by carbonic anhydrase (CA) (Moroney and Ynalvez, 2007). This process would eliminate the isotopic difference between $\mathrm{HCO}_{3}{ }^{-}$and $\mathrm{CO}_{2}$ and make the two carbon sources isotopically indistinguishable (Riebesell and Wolf-Gladrow, 1995). Our previous study found that the activity of external CA was positively correlated with the density of Chlorophyta and Cyanophyta in the karst reservoirs (Wu et al., 2008). So, it is expected that with their rapid growth, Chlorophyta and Cyanophyta begin to convert $\mathrm{HCO}_{3}^{-}$into $\mathrm{CO}_{2}$ by external $\mathrm{CA}$ due to the lack of $\mathrm{CO}_{2}$ availability. This $\mathrm{CCM}$ may result in high $\delta^{13} \mathrm{C}$ in these algae. Furthermore, Cyanophyta possess Rubisco II, for which the maximum carbon isotopic fractionation is $22 \%$, lower by $8 \%$ o than $\varepsilon_{\mathrm{p}}$ via Rubisco I that belongs to green algae and diatoms (Hayes, 2001). On the basis of our dataset, Dinophyta, like Chlorophyta, seemed to have a $\mathrm{CCM}$, however, further physiological evidence is needed to support this hypothesis.

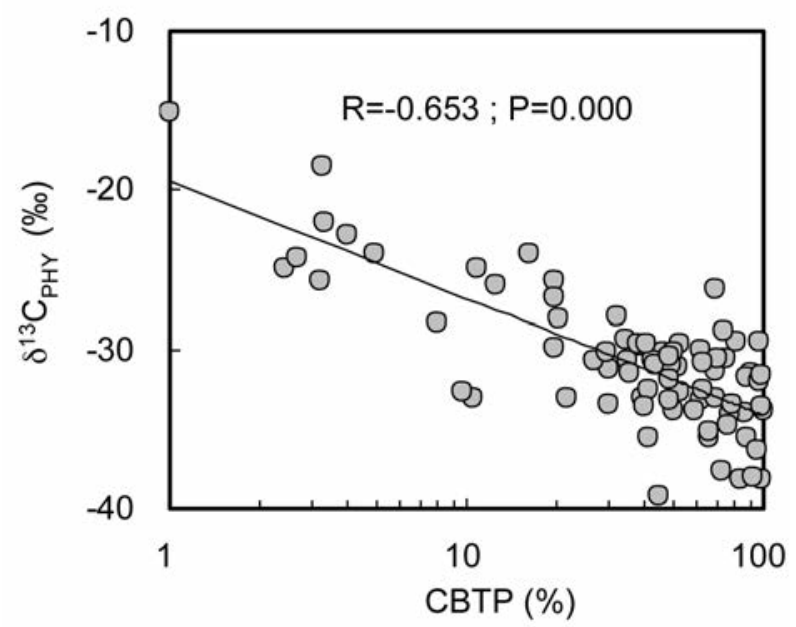

Fig. 7. Scatter plot of carbon stable isotope composition of phytoplankton $\left(\delta^{13} \mathrm{C}_{\mathrm{PHY}}\right)$ vs contribution of Bacillariophyta (CBTP) to total phytoplankton. 


\section{Mechanisms controlling the carbon stable isotope composition of phytoplankton}

There were several factors controlling $\delta^{13} \mathrm{C}_{\mathrm{PHY}}$ in freshwater ecosystem. In summer, with high $\mathrm{T}$, Chlorophyta, Dinophyta, and Cyanophyta bloomed and assimilated dissolved $\mathrm{CO}_{2}$ actively. When the concentration of dissolved $\mathrm{CO}_{2}$ was less than $10 \mu \mathrm{mol} \mathrm{L}{ }^{-1}$, these algal groups shifted to use $\mathrm{HCO}_{3}{ }^{-}$as their carbon source. This shift from $\mathrm{CO}_{2}$ to $\mathrm{HCO}_{3}{ }^{-}$and rapid algal growth resulted in high $\delta^{13} \mathrm{C}_{\mathrm{PHY}}$ in summer. In autumn, $\mathrm{T}$ decreased and total phytoplankton biomass also began to decrease. Nonetheless, the CBTP increased and this resulted in a decrease of $\delta^{13} \mathrm{C}_{\mathrm{PHY}}$. Temeperature decreased in winter and Bacillariophyta became the dominant algal group and consequently the phytoplankton had low $\delta^{13} \mathrm{C}$ values. Water $\mathrm{T}$ increased in spring and Chlorophyta became the dominant phytoplankton in some eutrophic reservoirs, while Bacillariophyta still dominated in other reservoirs. Therefore, $\delta^{13} \mathrm{C}_{\mathrm{PHY}}$ showed a large variation within reservoirs in spring. Multiple regression equations of $\delta^{13} \mathrm{C}_{\mathrm{PHY}}$ quantitatively expressed the relationship between $\delta^{13} \mathrm{C}_{\mathrm{PHY}}$ and its controlling factors. For instance, $\delta^{13} \mathrm{C}_{\mathrm{PHY}}$ theoretically decreased by 5.3\% with the increase of CBTP from $1 \%$ to $100 \%$, as show in Tab. 4. Therefore, the influence of biological factors such as CBTP and T-PHY on $\delta^{13} \mathrm{C}_{\mathrm{PHY}}$ could be equal to, or more than, that of physical and chemical factors such as $\mathrm{T}$ and $\mathrm{HCO}_{3}^{-}$.

Carbon isotope fractionation showed a significant negative correlation with $\delta^{13} \mathrm{C}_{\mathrm{PHY}}$, but a weak correlation with

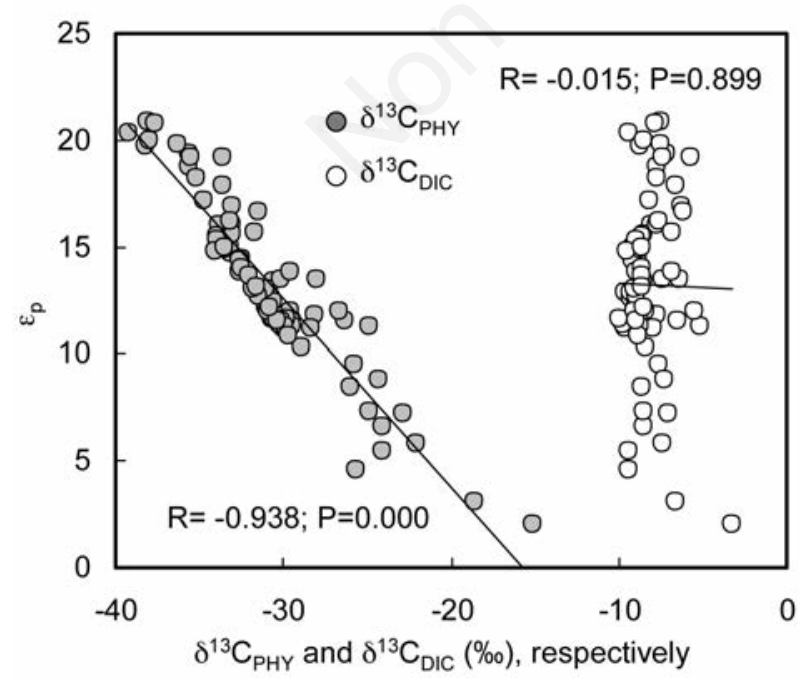

Fig. 8. Scatter plots of carbon isotope fractionation $\left(\varepsilon_{\mathrm{p}}\right) v s$ carbon stable isotope composition of phytoplankton $\left(\delta^{13} \mathrm{C}_{\mathrm{PHY}}\right)$, and carbon isotope fractionation $v s$ carbon stable isotope composition of dissolved inorganic carbon $\left(\delta^{13} \mathrm{C}_{\mathrm{DIC}}\right)$. $\delta^{13} \mathrm{C}_{\mathrm{DIC}}$ (Fig. 8), indicating the main influence of $\delta^{13} \mathrm{C}_{\mathrm{PHY}}$ on $\varepsilon_{\mathrm{p}}$. This was attributed to larger variation of $\delta^{13} \mathrm{C}_{\mathrm{PHY}}$ than that of $\delta^{13} \mathrm{C}_{\mathrm{DIC}}$. Therefore, the main factors influencing $\varepsilon_{\mathrm{p}}$ were evaluated by their influences on $\delta^{13} \mathrm{C}_{\mathrm{PHY}}$.

There were weak relationships between $\delta^{13} \mathrm{C}_{\mathrm{PHY}}$ and TP and between $\delta^{13} \mathrm{C}_{\mathrm{PHY}}$ and TN (Tab. 3). However, TN was significantly correlated with $\delta^{13} \mathrm{C}_{\mathrm{PHY}}$ in April and July at the 0.05 level (Fig. 5). This could be attributed to passive reduction of TN by algal uptake. Therefore, chemical trophic state indices (i.e. TP and $\mathrm{TN}$ ) were not important direct controlling factors of $\delta^{13} \mathrm{C}_{\mathrm{PHY}}$ on a regional scale.

\section{CONCLUSIONS}

The carbon stable isotope composition of phytoplankton showed substantial and systematic differences within seasons and reservoirs. An increase of $\mathrm{T}$ and a shift from $\mathrm{CO}_{2}$ to $\mathrm{HCO}_{3}^{-}$as a carbon source increased $\delta^{13} \mathrm{C}_{\mathrm{PHY}}$. The carbon stable isotope composition of phytoplankton tended to be lower when Bacillariophyta were dominant, as in January, and April, but tended to be higher when Chlorophyta and Dinophyta were dominant, as in July. This study indicated that the effect of taxonomic differences on $\delta^{13} \mathrm{C}_{\mathrm{PHY}}$ must be considered to explain the $\delta^{13} \mathrm{C}$ of organic matter in lacustrine ecosystems.

\section{ACKNOWLEDGMENTS}

The authors are grateful to X. Liu and A. Dang for assistance in sample collection in the field and experimental work in laboratory; G. Li and N. An for assistance with carbon isotope analyses. They are also grateful to Stephen C. Maberly and two reviewers for their valuable comments and suggestions on this manuscript.

This study was financially supported by the National Natural Science Foundation of China (Grant no. 41021062) and by the Foundation of Chinese Academy of Sciences (Grant no. kzcx2-ew-102 and kzcx2-yw-137).

\section{REFERENCES}

Atekwana EA, Krishnamurthy RV, 1998. Seasonal variations of dissolved inorganic carbon and $\delta^{13} \mathrm{C}$ of surface water: application of a modified gas evolution technique. J. Hydrol. 205:265-278.

Bade DL, Pace ML, Cole JJ, Carpenter SR, 2006. Can algal photosynthetic inorganic carbon isotope fractionation be predicted in lakes using existing models? Aquat. Sci. 68:142-153.

Barth JAC, Veizer J, 1999. Carbon cycle in St. Lawrence aquatic ecosystems at Cornwall (Ontario), Canada: seasonal and spatial variations. Chem. Geol. 159:107-128.

Brett MT, Kainz MJ, Taipale SJ, Seshan H, 2009. Phytoplankton, not allochthonous carbon, sustains herbivorous zooplankton production. PANS 106:21197-21201.

Buchanan DL, Corcoran BJ, 1959. Sealed tube combustions for the determination of carbon-14 and total carbon. Anal. Chem. 31:1635-1638. 
Burkhardt S, Riebesell U, Zondervan I, 1999. Effect of growth rate, $\mathrm{CO}_{2}$ concentration, and cell size on the stable carbon isotope fractionation in marine phytoplankton. Geochim. Cosmochim. Ac. 63:3729-3741.

Cassar N, Laws EA, Bidigare RR, Popp BN, 2004. Bicarbonate uptake by Southern Ocean phytoplankton. Global Biogeochem. Cy. 18:1-10.

Craig H, 1953. The geochemistry of stable carbon isotopes. Geochim. Cosmochim. Ac. 3:53-92.

Descolas-Gros C, Fontugne MR, 1990. Stable carbon isotope fractionation by marine phytoplankton during photosynthesis. Plant Cell Environ. 13:207-218.

Doi H, Kikuchi E, Shikano S, Takagi S, 2010. Differences in nitrogen and carbon stable isotopes between planktonic and benthic microalgae. Limnology 11:185-192.

EPA, 1988. Environmental quality standard for surface water. State standard of the People's Republic of China (GB 383888). Environmental Protection Administration of China. China Environmental Science Press, Beijing, China.

Finlay JC, Power ME, Cabana G, 1999. Effects of water velocity on algal carbon isotope ratios: implications of river food web studies. Limnol. Oceanogr. 44:1198-1203.

Freeman KH, Hayes JM, 1992. Fractionation of carbon isotopes by phytoplankton and estimates of ancient $\mathrm{CO}_{2}$ levels. Global Biogeochem. Cy. 6:185-198.

Fry B, 1996. ${ }^{13} \mathrm{C} /{ }^{12} \mathrm{C}$ fractionation by marine diatoms. Mar. Ecol. -Prog. Ser. 134:283-294.

Grey J, Jones RI, Sleep D, 2000. Stable isotope analysis of the origins of zooplankton carbon in lakes of differing trophic state. Oecologia 123:232-240.

Gu B, Chapman AD, Schelske CL, 2006. Factors controlling seasonal variations in stable isotope composition of particulate organic matter in a soft water eutrophic lake. Limnol. Oceanogr. 51:2837-2848.

Gu B, Schelske CL, Waters MN, 2011. Patterns and controls of seasonal variability of carbon stable isotope composition of particulate organic matter in lakes. Oecologia 165:10831094.

Hayes JM, 2001. Fractionation of carbon and hydrogen isotopes in biosynthetic processes. Rev. Mineral. Geochem. 43:225277.

Hinga KR, Arthur MA, Pilson MEQ, Whitaker D, 1994. Carbon isotope fractionation by marine phytoplankton in culture: the effects of $\mathrm{CO}_{2}$ concentration, $\mathrm{pH}$, temperature, and species. Global Biogeochem. Cy. 8: 91-102.

Johnston AM, 1996. The effect of environmental variables on $\delta^{13} \mathrm{C}$ discrimination by two marine phytoplankton. Mar. Ecol.-Prog. Ser. 132:257-263.

Jones RI, Grey J, Sleep D, Quarmby C, 1998. An assessment, using stable isotopes, of the importance of allochthonous organic carbon sources to the pelagic food web in Loch Ness. P. R. Soc. B 265:105-111.

Laws EA, Popp BN, Bidigare RR, Kennicutt MC, Macko SA, 1995. Dependence of phytoplankton carbon isotopic composition on growth rate and $\left[\mathrm{CO}_{2}\right]$ aq: theoretical considerations and experimental results. Geochim. Cosmochim. Ac. 6:1131-1138.

Lehmann MF, Bernasconi SM, McKenzie JA, Barbieri A, Simona M, Veronesi M, 2004. Seasonal variation of the $\delta^{13} \mathrm{C}$ and $\delta^{15} \mathrm{~N}$ of particulate and dissolved carbon and nitrogen in Lake Lugano: constraints on biogeochemical cycling in a eutrophic lake. Limnol. Oceanogr. 49:415-429.

Li KW, Smith JC, Platt T, 1984. Temperature response of photosynthetic capacity and carboxylase activity in Arctic marine phytoplankton. Mar. Ecol.-Prog. Ser. 17:237-243.

Liu CQ, 2007. Earth surface biogeochemical processes and mass cycles: karstic catchment erosions and bioelements cycles in Southwest China. [in Chinese]. Science Press, Beijing, China.

Maberly SC, 1996. Diel, episodic and seasonal changes in $\mathrm{pH}$ and concentration of inorganic carbon in a productive lake. Freshwater Biol. 35:579-598.

Marty J, Planas D, 2008. Comparison of methods to determine algal $\delta^{13} \mathrm{C}$ in freshwater. Limnol. Oceanogr.-Meth. 6:5163.

Milligan HE, Pretzlaw TD, Humphries MM, 2010. Stable isotope differentiation of freshwater and terrestrial vascular plants in two subarctic regions. Ecoscience 17:265-275.

Mook WG, Bommerson JC, Staverman WH, 1974. Carbon isotope fractionation between dissolved bicarbonate and gaseous carbon dioxide. Earth Planet. Sc. Lett. 22:169-176.

Moroney JV, Ynalvez RA, 2007. A proposed carbon dioxide concentration mechanism in Chlamydomonas reinhardtii. Eukaryot. Cell 6:1251-1259.

Popp BN, Laws EA, Bidigare RR, Dore JE, Hanson KL, Wakeham SG, 1998. Effect of phytoplankton cell geometry on carbon isotopic fractionation. Geochim. Cosmochim. Ac. 62:69-77.

Post DM, 2002. Using stable isotopes to estimate trophic position: models, methods, and assumptions. Ecology 83:703718.

Rau GH, Riebesell U, Wolf-Gladrow D, 1996. A model of photosynthetic ${ }^{13} \mathrm{C}$ fractionation by marine phytoplankton based on diffusive molecular $\mathrm{CO}_{2}$ uptake. Mar. Ecol.-Prog. Ser. 133:275-285.

Rau GH, Takahashi T, Marais DJD, 1989. Latitudinal variations in plankton $\delta^{13} \mathrm{C}$ : implications for $\mathrm{CO}_{2}$ and productivity in past oceans. Nature 341:516-518.

Rau GH, Takahashi T, Marais DJD, Repeta DJ, Martin JH, 1992. The relationship between $\delta^{13} \mathrm{C}$ of organic matter and $\left[\mathrm{CO}_{2}\right.$ (aq)] in ocean surface water: data from a JGOFS site in the northeast Atlantic Ocean and a model. Geochim. Cosmochim. Ac. 56:1413-1419.

Riebesell U, Wolf-Gladrow D, 1995. Growth limits on phytoplankton. Nature 373:28.

Rost B, Zondervan I, Riebesell U, 2002. Light-dependent carbon isotope fractionation in the coccolithophorid Emiliania huxleyi. Limnol. Oceanogr. 47:120-128.

Sackett WM, Eckelmann W, Bender M, Bé AW, 1965. Temperature dependence of carbon isotope composition in marine plankton and sediments. Science 148:235-237.

Smyntek PM, Maberly SC, Grey J, 2012. Dissolved carbon dioxide concentration controls baseline stable carbon isotope signatures of a lake food web. Limnol. Oceanogr. 57:12921302.

Stumm W, Morgan JJ, 1981. Aquatic chemistry. John Wiley \& Sons, New York, USA: 1040 pp.

Tao FX, Aucour AM, Sheppard SMF, Liu CQ, Leng XT, Wang SL, Liu GS, Xu WB, 2001. Evaluation of the sealed-tube low temperature combustion method for the ${ }^{13} \mathrm{C} /{ }^{12} \mathrm{C}$ and 
${ }^{2} \mathrm{H} /{ }^{1} \mathrm{H}$ ratio determinations of cellulose nitrate. Chinese J. Chem. 19:1089-1096.

Thompson PA, Calvert SE, 1994. Carbon-isotope fractionation by a marine diatom: The the influence of irradiance, daylength, $\mathrm{pH}$, and nitrogen source. Limnol. Oceanogr. 39:1835-1844.

Vuorio K, Meili M, Jouko S, 2006. Taxon-specific variation in the stable isotopic signatures $\left(\delta^{13} \mathrm{C}\right.$ and $\left.\delta^{15} \mathrm{~N}\right)$ of lake phytoplankton. Freshwater Biol. 51:807-822.

Wang B, Liu CQ, Wang F, Yu Y, Zhang L, 2008. The distributions of autumn picoplankton in relation to environmental factors in the reservoirs along the Wujiang River in Guizhou Province, SW China. Hydrobiologia 598:35-45.

Wang F, Wang B, Liu CQ, Wang Y, Guan J, Liu X, Yu Y, 2011. Carbon dioxide emission from surface water in cascade reservoirs-river system on the Maotiao River, southwest of China. Atmos. Environ. 45:3827-3834.
Wetzel RG, 2001. Limnology: lake and river ecosystems. $3^{\text {rd }}$ ed. Academic Press, San Diego, USA: 1006 pp.

Wong WW, Sackett WM, 1978. Fractionation of stable carbon isotopes by marine phytoplankton. Geochim. Cosmochim. Ac. 42:1809-1815.

Wu Y, Li P, Wang B, Liu CQ, He M, Chen C, 2008. Composition and activity of external carbonic anhydrase of microalgae from Karst Lakes in China. Phycol. Res. 56:76-82.

Yoshii K, Melnik NG, Timoshkin OA, Bondarenko NA, Anoshko PN, Yoshioka T, Wada E, 1999. Stable isotope analyses of the pelagic food web in Lake Baikal. Limnol. Oceanogr. 44:502-511.

Zhang ZS, Huang XF, 1991. Methods in freshwater plankton study. [in Chinese]. Science Press, Beijing, China.

Zohary T, Erez J, Gophen M, Berman-Frank I, Stiller M, 1994. Seasonality of stable carbon isotopes within the pelagic food web of Lake Kinneret. Limnol. Oceanogr. 39:1030-1043. 